\title{
Techno-economic Analysis of Energy Storage System for Wind Farms: The UK Perspective
}

\author{
David Campos-Gaona \\ Electronic and Electrical \\ Engineering \\ University of Strathclyde \\ Glasgow, United Kingdom \\ d.campos-gaona@strath.ac.uk
}

\author{
Ander Madariaga \\ Offshore Renewable Energy \\ CATAPULT \\ Glasgow, United Kingdom \\ ander.madariaga@ore.catapult. \\ org.uk
}

\author{
Jawwad Zafar \\ Power Networks \\ Demonstration Centre \\ University of Strathclyde \\ Cumbenauld, United Kingdom \\ jawwad.zafar@strath.ac.uk
}

\author{
Olimpo Anaya-Lara \\ Electronic and Electrical \\ Engineering \\ University of Strathclyde \\ Glasgow, United Kingdom \\ olimpo.anaya- \\ lara@strath.ac.uk
}

\author{
Graeme Burt \\ Electronic and Electrical Engineering \\ University of Strathclyde \\ Glasgow, United Kingdom \\ graeme.burt@strath.ac.uk
}

\begin{abstract}
This paper evaluates the modern trends of energy storage in the $U K$ and reviews its application in the context of wind energy systems. This research takes into account the advantages/disadvantages and trends of different technical options of energy storage technology based on modern and future industry and government projects. Additionally, this research identifies and quantifies, in terms of profitability, the revenue streams available in the UK for energy storage projects, using the most up-to-date information. This research also identifies the revenue streams suitable for wind power and energy storage, and discusses the current UK regulatory framework for its implementation. The results of this research are of high value for those looking into the techno-economic aspects of wind energy integration with energy storage and provide a framework where industry and universities can position development or research efforts with a fresh view of the opportunities ahead.
\end{abstract}

Keywords-Energy Storage, Batteries, Wind Farms, Economics, Revenue Streams, United Kingdom.

\section{INTRODUCTION}

The application of energy storage systems (ESS) for the integration of renewable energies to the electricity network has been a topic of interest for utility companies, developers and researchers. These systems offer potential benefits to the grid in terms of renewable energy time-shifts, renewable capacity firming and wind generation grid integration. In addition to these benefits, ESS in general have the capacity to improve electric power operation in terms of electric supply, ancillary services, transmission support and end-user cost of electricity [1]. However, the high price of compatible technologies of ESS and a lack of technological maturity made it difficult to develop a successful business case for the application of ESS along with large-scale renewable energies. Interestingly, this scenario is changing thanks to the rapid decrease in price of some electrochemical ESS. Additionally, consumer markets and the electric vehicle industry are driving up the maturity of some ESS technologies.
This newly developed scenario opens the opportunity to reevaluate the application of ESS with large-scale wind energy systems in the context of today's grid requirements. A very comprehensive work regarding energy storage connected to grid power systems can be found in [2] where technology, cost, and methods are discussed in detail. This resource however, has no specific focus in the grid requirements of a specific country. A similar work which focuses on the Australian grid requirements can be found in [3]. For the UK case, some placespecific analyses have been carried out like the one in [4]. Notwithstanding, none of the aforementioned reports focus on the specific case of energy storage with wind energy systems.

The research presented in this paper evaluates the modern trends of ESS in the UK and reviews its application in the context of wind energy systems. The research takes into account the advantages/disadvantages and trends of the different technical options for implementations of the technology (i.e. wind turbine local storage vs wind farm wide storage) based on the outcomes of past industry projects and the author's insight. Additionally, this research identifies and quantifies, in terms of profitability, the revenue streams available in the UK for energy storage projects, using the most up-to-date information. This research also identifies the revenue streams suitable for wind power and energy storage, and discusses the current UK regulatory framework for its implementation.

\section{MODERN APPLICATION OF ENERGY STORAGE IN THE UK GRID}

Electricity-only storage solutions vary from large incumbents, such as pumped hydro, through to newer, distributed alternatives. In the case of gas-based energy storage, the market varies from large-scale compressed air energy storage (CAES) in salt caverns, underwater storage vessels or tanked solutions, to above ground liquid air energy storage (LAES) solutions; ammonia/hydrogen via compressors and electrolyzers. Solid-state batteries offer a range of 
electromechanical storage solutions including advanced chemical batteries and capacitors. Flow batteries store energy directly in an electrolyte solution to give a longer cycle life and faster response times. Thermal storage captures heat to create energy on demand. Finally, flywheels store rotational energy in a high speed rotating mass.

The electricity grid makes use of all the aforementioned technologies; however, the factors that define the selection of a given ESS technology are based in the particular needs of the project, life-cycle cost and performance (round-trip efficiency, energy density, cycle life, capacity fade etc.). Reliability, maturity and safety also play an important role in the selection or exclusion of a given technology.

Fig. 1 shows a scope of different energy storage technologies organized by power capacity and discharge time [1]. The figure shows that most of the applications for grid energy storage can, nowadays, be served by either solid or flow battery energy systems. Governments and industries in the UK recognize this trend.

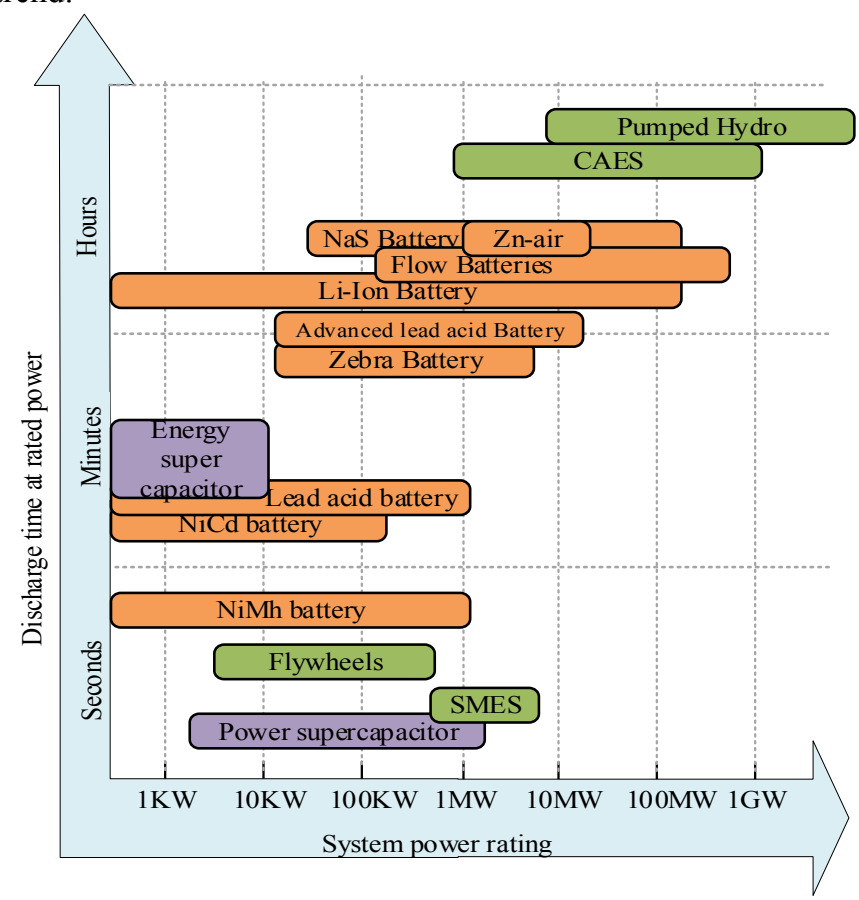

Fig. 1 Energy storage technologies chart.

The UK Government published its Modern Industrial Strategy on January 2017 [5], with energy storage, and particularly battery technology, highlighted as a priority area for the future. The document identifies electric vehicles, consumer electronics and smart energy systems as areas that would benefit from the developments in battery technology. The document also stated that the UK government will consider the case for a new research institution focused to work in battery technology. Since then, the government began the launch of a $£ 246 \mathrm{~m}$ investment into the development of new battery technology, beginning with the Faraday Challenge, as part of its industrial strategy. The Faraday Challenge is a series of competitions over the next four years to boost the research and development of expertise in battery technology, with the final aim of creating a center for energy storage research [6].
All types of Battery Energy Storage (BES) systems offer pros and cons in terms of capacity, discharge duration, energy density, safety, environmental risk and cost. A brief comparison between the main technological aspects of the main BES technologies is shown in Fig. 2, where, for example, it can be seen that the Redox flow batteries have advantages in extended lifetime and improved environmental impact. However, since this is a new technology, the cost is higher when compared to the other alternatives. Conversely, Zebra batteries, which are from the family of Sodium-Sulphur chemistries, provide low cost and high efficiency. The lifetime, however, is short.

In spite of this, energy storage systems utilizing Li-ion batteries are, by far, the most widely used for modern energy storage systems. This is primarily due to their high energy density and the steady decrease in cost.

\section{Lifetime/cyles}

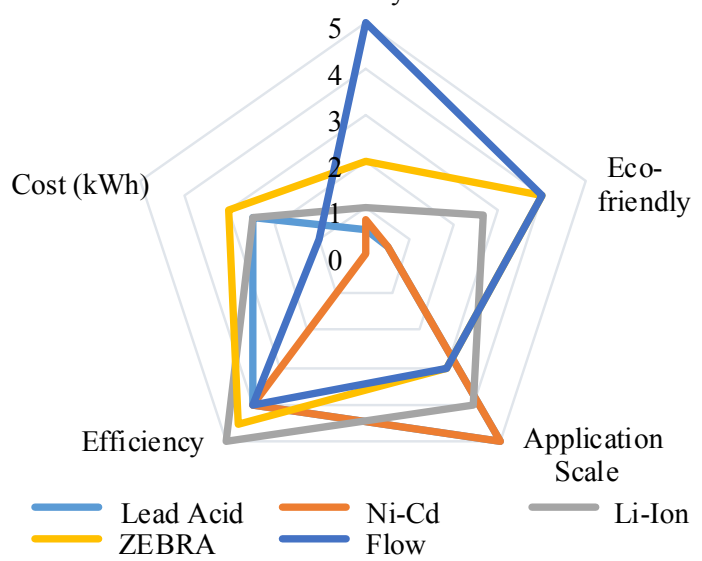

Fig. 2 Technological comparison of BES

Fig. 3 shows the price evolution of the $\mathrm{Li}$-ion batteries, based in several high-profile reports $[3,4,7-10]$ and $4^{\text {th }}$ order polynomials to approximate price trends. The data shows a tendency to decline in price that is acknowledged unanimously. The average price shows a decline of $40 \%$ from 2014 prices against 2018 prices.

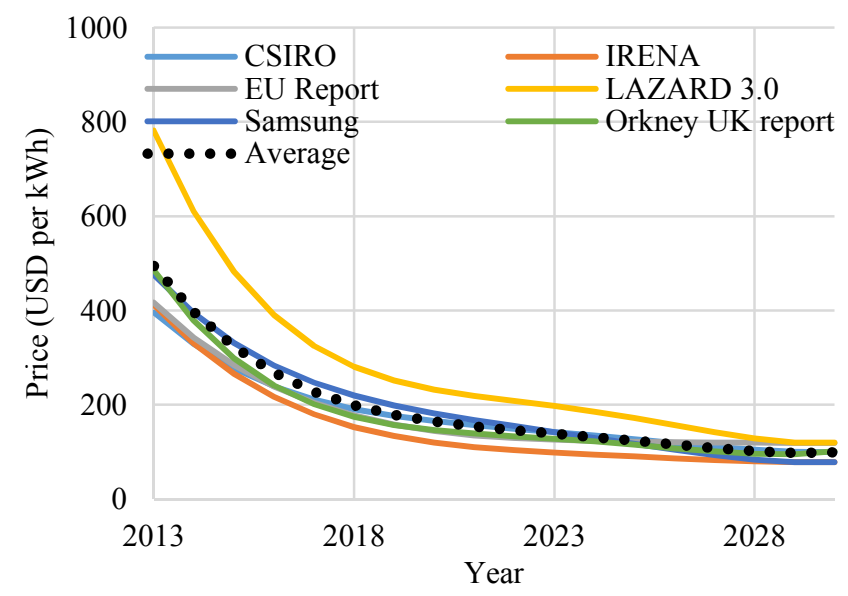

Fig. 3 Price evolution of Li-ion batteries.

This sharp decline in the cost of Li-ion batteries has allowed BES projects to bid to provide frequency response services at extremely competitive prices in the UK. For example, during 
the National Grid pilot tender in July 2016 for enhanced frequency response services, out of a list of some 64 prequalified bidders (where 61 of the 64 projects on the final list were battery-based systems) National Grid picked eight vendors with a combined 201 megawatts of Li-ion-based energy storage projects. The range in size of the projects was between 10 and 49 megawatts apiece, with a total value of $£ 66$ million. The prices of winning bidders ranged between $£ 7$ $12 / \mathrm{MW} /$ Hour where the median bid price was approximately $£ 20$ per MW per hour of service.

Concerning worldwide implementation, Li-ion battery technology dominates, by a very large margin, grid-connected BES projects. To evidence this, Fig. 4 shows the number of operational/contracted/announced grid energy storage projects above 10 MW (as per 2018 DOE Energy Storage Database [11]). As seen in Fig. 4, Li-ion storage dominates the number of projects for the 10-100 MW range, with the sole exception of the 200 MW Redox-flow energy storage system currently under construction in Dalian, China.

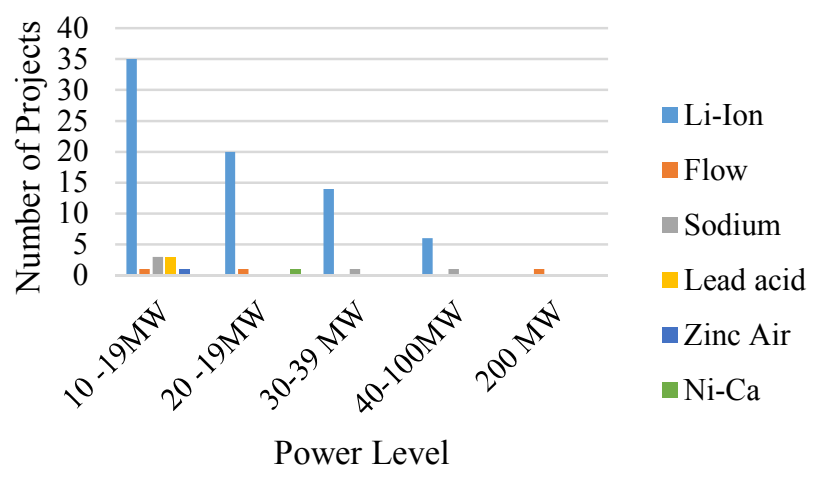

Fig. 4 Operational/contracted/announced grid-connected energy storage systems above $10 \mathrm{MW}$.

The discharge time of the projects enumerated in Fig. 4 varies from minutes to several hours. In spite of this, Li-ion became the overwhelming choice for projects with discharge periods up to 4 hours, as it can be seen in Fig. 5 .

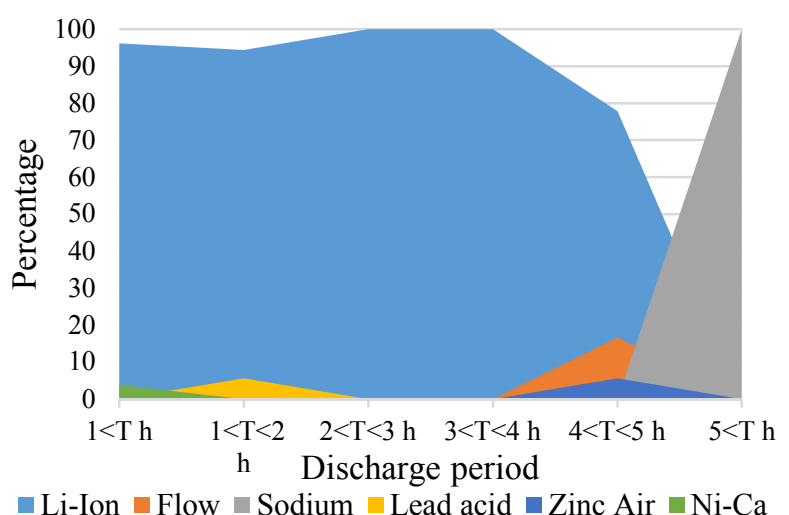

Fig. 5 Percentage of BES technology penetration in operational/contracted/announced grid-connected energy storage projects.
Fig. 5 also shows that the current limit of discharge time for modern Li-ion systems is 4.5 hours.

While the use of Li-ion batteries is nothing new, the increase in the size, complexity and energy density of the modern chemistries have a negative counterpart in terms of safety risks. One of these risks is the thermal runaway cycle [12], where excessive heat (created by either internal cell defects, mechanical failures/damages or overvoltage) keeps creating more heat that eventually leads to high temperatures, gas buildup and potential explosive rupture of the battery cell, resulting in fire and/or explosion. Events like the 2011 Chevrolet Volt fire, the 2011 and 2012 fires at Kahuku Wind Farm (Hawaii), the 2013 Dreamliner 787 fire and the 2016 Galaxy Note 7 smartphone explosion problem evidence the hazards of highdensity battery chemistries.

In this regard, alternatives to Li-ion such as Redox Flow batteries and Zinc-Air offer advantages in safety, power density and extended duration without the fire/explosion risks associated with Li-ion batteries [13]. Additionally, the nature of the flow batteries makes it possible to, independently select, the amount of power and energy of the system. As seen in Fig. 4 and Fig. 5, some modern projects are already adapting these technologies with an impressive amount of power and energy storage capability.

Fig. 6 shows the price trend (in GBP) of Redox Flow batteries based in $[7,8]$.

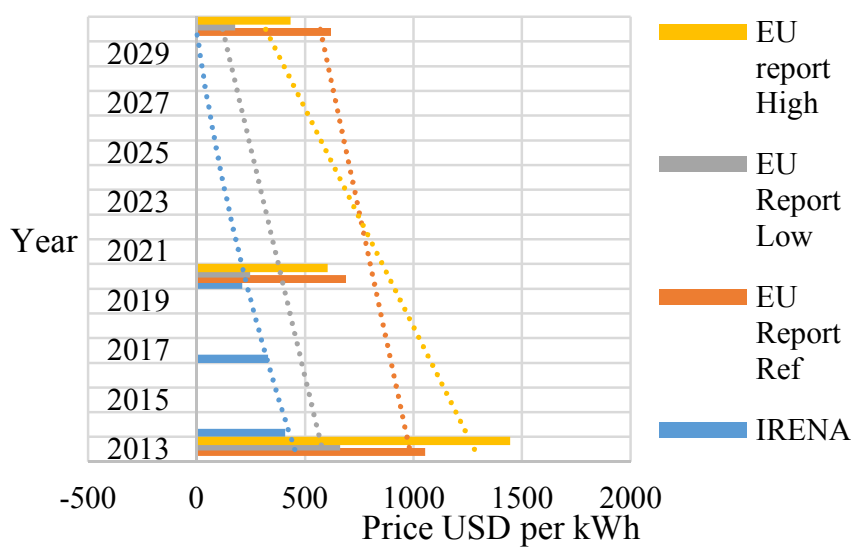

Fig. 6 Price evolution of flow batteries.

Notwithstanding, the continuous price decline and improvements in Li-ion technology, added to the conservative approach of utilities to adopt novel energy storage systems to the grid, keeps the Li-ion adoption trend way ahead of the emerging rivals.

\section{SELECTION OF ENERGY STORAGE LOCATION FOR WIND TURBINES}

The location of energy storage for wind turbines in current and past commercial applications has taken the shape of being individually localized at turbine level or aggregated at wind farm level.

Academic studies analyzing the smoothing capability of both aggregated and individually localized ESS for wind turbines have shown that both configurations achieve similar fluctuation 
in harmonic content values (i.e. wind power smoothing) and power quality improvement in local voltage and system frequency [14]. However, the market trends in this regard have favored the aggregated wind-farm-level storage.

An example of turbine-level energy storage was the range of Brilliant wind turbines deployed by GE in 2013, which integrated $50 \mathrm{kWh}$ of battery storage based on the GE Durathon battery technology (Sodium-Nickel-Chloride). The energy storage system was located in a nearby ground pad and was used to capitalize three separate revenue streams, namely: wind power capacity firming, frequency regulation and renewable energy time-shifting. Although the concept of battery-enhanced wind turbines is still used by GE, there are only 3 known instances where the technology was deployed. Additionally, the production of Durathon batteries significantly reduced in 2015 amid what GE said was a slow-to-develop market for grid-scale energy storage and because of the conservative approach, utilities have in adopting emerging battery technologies.

An example of wind-farm level storage is the $2 \mathrm{MWh}$ battery energy storage system at the onshore substation of the $90 \mathrm{MW}$ Burbo Bank offshore wind farm, which focuses mainly on frequency regulation (under construction 2017). Another example is the $22 \mathrm{MWh}$ energy storage system for the Pen $\mathrm{y}$ Cymonedd Wind Farm in Wales, using BMW Li-ion batteries inherited from the electric vehicle industry (under construction sept. 2017). This application will focus mainly on enhanced frequency response during frequency deviation scenarios. Similar wind-farm level storage systems have been deployed or are under construction in USA, The Netherlands, Japan and China.

Some future projects, such as the Batwind project for floating wind turbines, has presented the idea of using energy storage systems at the offshore turbine structure (for floating wind turbines) [15], and some academic papers have presented the idea of energy storage located either at the nacelle or tower of the wind turbines $[16,17]$. This approach, however, implies the idea of loading the turbine structure with the weight of the energy storage devices. Notwithstanding, this practice goes against the current trend in design of wind turbines where lighter structures are being developed in order to reduce structural/foundation costs and improve the scalability of future wind energy systems. In addition to this, the deployment of energy storage at wind turbine level for offshore systems implies additional problems in terms of safety, environmental impact and in the specific case of offshore wind turbines, added losses that makes it almost impossible to devise a feasible business case for the project.

The evidence based on the industry trends and this research shows that wind-farm-level energy storage, rather than individually localized, is better suited to stack revenue streams and thus maximize the profitability of the project.

\section{REVENUE STREAMS FOR WIND POWER WITH ENERGY STORAGE SYSTEMS: THE UK PERSPECTIVE}

Unlike renewable energy, there are no simple revenue incentives for storage developers in the UK equivalent to contract-for-difference or feed-in tariffs. Nonetheless, there are
TABLE I

STORAGE REVENUE STREAMS IN THE UK

\begin{tabular}{|c|c|c|}
\hline $\begin{array}{l}\text { Revenue } \\
\text { stream }\end{array}$ & Description & $\begin{array}{c}\text { Suitable energy } \\
\text { storage }\end{array}$ \\
\hline $\begin{array}{c}\text { Enhanced } \\
\text { frequency } \\
\text { response (EFR) }\end{array}$ & $\begin{array}{l}\text { The fastest frequency response } \\
\text { service looking to avoid a } 1 \% \\
\text { deviation from nominal frequency }\end{array}$ & $\begin{array}{l}\text { Li-Ion Battery, } \\
\text { Flow Battery } \\
\text { Flywheel, } \\
\text { Capacitor }\end{array}$ \\
\hline $\begin{array}{l}\text { Firm frequency } \\
\text { response (FFR) }\end{array}$ & $\begin{array}{l}\text { This service is provided as either } \\
\text { static or dynamic. Static provision } \\
\text { responds with a specified power } \\
\text { at a set frequency deviation, } \\
\text { while dynamic provision delivers } \\
\text { a power response proportional to } \\
\text { the deviation for target frequency }\end{array}$ & $\begin{array}{l}\text { Li-Ion, Flow } \\
\text { Flywheel, } \\
\text { Capacitor, } \\
\text { Pump Hydro }\end{array}$ \\
\hline Fast reserve & $\begin{array}{l}\text { Provides the capability to protect } \\
\text { the security of supply from } \\
\text { unforeseen demand increases or } \\
\text { generation unavailability }\end{array}$ & $\begin{array}{c}\text { Flow, Pump } \\
\text { Hydro }\end{array}$ \\
\hline $\begin{array}{c}\text { Short term } \\
\text { operating } \\
\text { reserve (STOR) }\end{array}$ & $\begin{array}{c}\text { Provides similar capabilities to } \\
\text { fast reserve service but with } \\
\text { significantly slower response } \\
\text { times. }\end{array}$ & $\begin{array}{l}\text { Flow, Pump } \\
\text { Hydro, CAES, } \\
\text { LAES. }\end{array}$ \\
\hline $\begin{array}{c}\text { Capacity market } \\
(\mathrm{CM})\end{array}$ & $\begin{array}{l}\text { This service ensures there is } \\
\text { sufficient generation capacity } \\
\text { during period of systems stress }\end{array}$ & $\begin{array}{l}\text { Li-Ion, Flow, } \\
\text { Pump Hydro, } \\
\text { CAES, LAES. }\end{array}$ \\
\hline Triad avoidance & $\begin{array}{l}\text { Triads are a section of the annual } \\
\text { transmission costs that } \\
\text { generators/ users of electricity } \\
\text { pay for generating/importing } \\
\text { during peak demand periods }\end{array}$ & $\begin{array}{l}\text { Li-Ion, Pump } \\
\text { Hydro, CAES, } \\
\text { LAES. }\end{array}$ \\
\hline $\begin{array}{c}\text { Capturing split } \\
\text { energy }\end{array}$ & $\begin{array}{l}\text { This service stores generated } \\
\text { electricity when a renewable } \\
\text { generator exceeds the grid export } \\
\text { capability and exports this energy } \\
\text { when there is capacity to do so. }\end{array}$ & $\begin{array}{l}\text { Li-Ion Battery, } \\
\text { Flow Battery, } \\
\text { Flywheel, } \\
\text { Capacitor, } \\
\text { CAES, LAES. }\end{array}$ \\
\hline $\begin{array}{c}\text { Managing } \\
\text { imbalance risk }\end{array}$ & $\begin{array}{l}\text { This service avoids the disparity } \\
\text { between the contractual } \\
\text { obligation of energy market } \\
\text { participants to generate/consume } \\
\text { electricity and their true level of } \\
\text { generation/consumption. }\end{array}$ & $\begin{array}{c}\text { Li-Ion Battery, } \\
\text { Flow Battery, }\end{array}$ \\
\hline $\begin{array}{c}\text { Wholesale price } \\
\text { arbitrage }\end{array}$ & $\begin{array}{l}\text { This service exploits the price } \\
\text { differential in wholesale markets } \\
\text { over time (buy cheap, sell } \\
\text { expensive) }\end{array}$ & $\begin{array}{l}\text { Li-Ion Battery, } \\
\text { Flow Battery, } \\
\text { LAES }\end{array}$ \\
\hline Black start & $\begin{array}{l}\text { This service enables the } \\
\text { transmission system to recover } \\
\text { from a total or partial shutdown. }\end{array}$ & $\begin{array}{l}\text { Pump Hydro, } \\
\text { CAES, LAES. }\end{array}$ \\
\hline
\end{tabular}

numerous revenue streams accessible for storage projects in the UK, operating in a wide range of roles with multiple beneficiaries and off-takers. Table I identifies and describes briefly the revenue stream accessible for energy storage using the nomenclature of National Grid. Notice that some of these revenue streams are beyond the reach of some storage technologies, as evidenced in the table.

Although different revenue streams can be targeted with a single energy storage system, not all of them offer the same amount of revenue nor are fully compatible between each other. The quantification of the different revenue streams in present day UK values is listed in Table II [18-24]. These values are an indicative range based on the full provision of the services.

Table II evidences that frequency response is currently the UK's most lucrative option on a GBP/MW basis. However, as 
TABLE II

\begin{tabular}{|c|c|}
\hline $\begin{array}{l}\text { Revenue } \\
\text { stream }\end{array}$ & Indicative Value \\
\hline EFR & $60-105 \mathrm{kf} / \mathrm{MW} /$ year \\
\hline $\begin{array}{l}\text { Firm Frequency } \\
\text { response (FFR) }\end{array}$ & $50-145 \mathrm{kf} / \mathrm{MW} /$ year \\
\hline Fast Reserve & 50-70kf/MW/year \\
\hline Short term & $20-35 \mathrm{kf} / \mathrm{MW} /$ year \\
\hline $\begin{array}{c}\text { Operating } \\
\text { reserve (STOR) }\end{array}$ & \\
\hline $\begin{array}{c}\text { Capacity Market } \\
\text { (CM) }\end{array}$ & $22.5 \mathrm{k} £ / \mathrm{MW} /$ year \\
\hline Triad Avoidance & $\begin{array}{c}\text { Region dependent } \\
\text { 30K£/MW/year S. Scotland } \\
\text { 2017/18 }\end{array}$ \\
\hline $\begin{array}{c}\text { Capturing Split } \\
\text { energy }\end{array}$ & Site dependent \\
\hline Managing & 7-30k£/MW/year. \\
\hline Imbalance risk & \\
\hline $\begin{array}{c}\text { Wholesale price } \\
\text { arbitrage }\end{array}$ & $20 \mathrm{k} / \mathrm{MW} /$ year \\
\hline Black Start & Undisclosed \\
\hline
\end{tabular}

explained in section II, the ongoing battery-led competition for this revenue stream is driving the revenue prices down.

Regarding Capacity Market contracts, one of the latest auctions in the UK (T-4 December 2016) was the first auction that battery storage won agreements in, with 501 MW of battery storage projects awarded with a 15 -year contract. Out of the 28 awarded projects, four of the battery projects previously successful in the EFR tender where also awarded with Capacity Market contracts.

Historically speaking, energy storage for wind energy has been linked to managing the imbalance risk as a primary focus, with the option of stacking other revenue streams that are somehow compatible, such as frequency response and/or capturing spilt energy.

Given the cost restriction of energy storage, it is of first importance to select the appropriate revenue stream for the case of wind energy systems, besides the usual task of managing the imbalance risk. For example, Li-ion batteries are well suited for providing EFR, which requires high power delivery sustained for a maximum of only $15 \mathrm{~min}$. However, while technically feasible, it is uneconomical for the same battery deployment to provide STOR services because of the huge number of battery cells that would be required in order to store energy to deliver for the required 2-hour minimum specified in the technical requirements of the service.

With regards to the current UK regulatory framework, special consideration should be given to the current and future regulations regarding revenue streams. For example, on June 2017 a modification to the connection and use of system code (CUSC) was proposed for the specific case of energy storage. The modification addressed the defect that under the current charging methodology, storage providers pay on both their charging and discharging volumes of energy (in addition to the costs implicit in the "cost of energy"). Storage providers are therefore contributing more towards the cost of balancing the system than other users. Storage providers, who compete with generators in the provision of ancillary services, are therefore at a competitive disadvantage, which is likely to distort market outcomes and disadvantage consumers. The solution to this defect has been proposed as a change in the charging methodology within section 14 of the CUSC to remove the charging cost of energy storage. An indicative decision for this request is expected in June 2018, with the decision implemented on CUSC on April 2019.

It is evident that the value of revenue streams based in "Arbitrage" (buying cheap, selling expensive) will be impacted directly depending on the June 2018 decision.

A more significant reform in the storage revenue landscape came when the National Grid announced a redesign of the suite of ancillary services that they procure. The major objectives of this redesign are to condense the current suite of 20 products down to three product groupings and to move from the existing rigid market structure to a more liquid and flexible model [25].

Based on the aforementioned UK regulatory framework, an optimal business case for energy storage for wind energy systems would require, besides the stacking of revenue streams, designing projects in a technical and contractual manner such that a change in the revenue stream stack can be implemented in the future. Additionally, the project must address the revenue interface risk when switching from revenue streams, making sure that it is able to do so in a technical, regulatory and commercially compatible way. This gives ample opportunity to industry and academia to research innovative control and communication design where ESS are able to respond in realtime to market signals, whilst also ensuring that the storage asset is performing within safe operating limits.

\section{CONCLUSIONS}

This work presents a picture of the current and future perspectives of integrating ESS with wind energy with a special focus on the UK.

The modern and future energy storage perspectives for the UK are dominated by BES, with Li-ion technology leading by an ample margin over other technologies given its ongoing price decrease. This price decrease has enabled a sustainable and increasing penetration of BES in the revenue stream market of the UK.

The best option to maximize the revenue streams from wind farms with ESS for both onshore or offshore case is to have wind-farm level storage rather than turbine-level storage.

The UK's selection of revenue streams for wind farms with ESS should not only focus on the highest rewarding revenue streams available and its compatibility, but also in the impending future changes that affect revenue streams in the regulatory framework of the UK.

\section{REFERENCES}

[1] B. Dunn, H. Kamath, and J.-M. Tarascon, "Electrical Energy Storage for the Grid: A Battery of Choices," Science, vol. 334, no. 6058, pp. 928935, 2011.

[2] A. A. Akhil et al., "DOE/EPRI electricity storage handbook in collaboration with NRECA," Sandia National Laboratories, 2015.

[3] T. Brinsmead, P. Graham, J. Hayward, E. Ratnam, and L. Reedman, "Future energy storage trends: an assessment of the economic viability, 
potential uptake and impacts of electrical energy storage on the NEM 2015-2035," CSIRO, Australia. Report No. EP 155039, 2015.

[4] A. Urquhart, "Trial of Orkeney Energy Storage Park SSET1009," Scottish and Southern Energy 2013.

[5] (2017). Building our Industrial Strategy. Available: https://www.gov.uk/government/uploads/system/uploads/attachment d ata/file/611705/building-our-industrial-strategy-green-paper.pdf

[6] (2017). Business Secretary to establish UK as world leader in battery technology as part of modern Industrial Strategy. Available: https://www.gov.uk/government/news/business-secretary-to-establishuk-as-world-leader-in-battery-technology-as-part-of-modern-industrialstrategy

[7] R. Kempener and E. Borden, "Battery storage for renewables: Market status and technology outlook," in "International Renewable Energy Agency, Abu Dhabi," 2015.

[8] "Energy Technology Reference Indicator projections for 2010-2050," European Commision, Luxembourg2014.

[9] M. Wilson, "Lazards's Levelized Cost of Storage Analysis-version 3.0," Lazard2017.

[10] B. Ricci and S. M. Jung, "Energy storage levelized cost assessment: Lithium-ion vs. combustion turbine," in 2015 IEEE 15th International Conference on Environment and Electrical Engineering (EEEIC), 2015, pp. 357-362.

[11] (2018). DOE Global Energy Storage Database. Available: https://www.energystorageexchange.org/projects

[12] T. H. Dubaniewicz and J. P. DuCarme, "Are Lithium Ion Cells Intrinsically Safe?," IEEE Transactions on Industry Applications, vol. 49, no. 6, pp. 2451-2460, 2013.

[13] Z. G. Yang, "Is this the ultimate grid battery?," IEEE Spectrum, vol. 54, no. 11, pp. 36-41, 2017.

[14] W. Li and G. Joos, "Comparison of Energy Storage System Technologies and Configurations in a Wind Farm," in 2007 IEEE Power Electronics Specialists Conference, 2007, pp. 1280-1285.

[15] Statoil. (2016). Battery Storage for offshore wind. Available: https://www.statoil.com/content/dam/statoil/documents/newsroomadditional-documents/news-attachments/batwind-presentation.pdf

[16] Z. Jiang and X. Yu, "Modeling and control of an integrated wind power generation and energy storage system," in 2009 IEEE Power \& Energy Society General Meeting, 2009, pp. 1-8.

[17] Y. Kim, J. Zhao, and R. J. Harrington, "Performance analysis of energy storage systems connected to a doubly fed induction generator," in 2015 IEEE Green Energy and Systems Conference (IGESC), 2015, pp. 30-34.

[18] N. Grid. (2016). Enhanced Frequency Response Market Information Report. Available: https://www.nationalgrid.com/sites/default/files/documents/EFR\%20M arket $\% 20$ Information $\% 20$ Report $\% 20 \mathrm{v} 1 . \mathrm{pdf}$

[19] N. Grid. (2018). System Balancing Reports. Available: https://www.nationalgrid.com/uk/electricity/market-operations-anddata/system-balancing-reports

[20] N. Grid. (2017). Firm Fast Reserve Post Assessment Tender Report July $2017 . \quad$ Available: https://www.nationalgrid.com/sites/default/files/documents/11_Market \%20Report $\% 20$ July\%202017.pdf

[21] N. Grid. (2017). STOR Market Information Report TR33. Available: https://www.nationalgrid.com/sites/default/files/documents/STOR $\% 20$ TR33\%20-\%20EXT.pdf

[22] OFGEM. (2017). Annual Report on the Operation of the Capacity Market in 2016/2017. Available: https://www.ofgem.gov.uk/system/files/docs/2017/06/annual_report_o $\underline{n}$ the operation of the capacity market in 2016-17.pdf

[23] N. Grid. (2018). Transmission network use of system (TNUoS) charges. Available: https://www.nationalgrid.com/uk/electricity/charging-andmethodology/transmission-network-use-system-tnuos-charges

[24] EWEA. (2015). Balancing Responsability and Cost of Wind Power Plants. Available: http://www.ewea.org/fileadmin/files/library/publications/positionpapers/EWEA-position-paper-balancing-responsibility-and-costs.pdf

[25] A. Sims. (2016). Simplification of Balancing Services. Available: http://powerresponsive.com/wp-content/uploads/2016/12/SWGMasterSlideDeck.pdf?mc cid $=$ ce03cdebde $\& m c \_$eid $=\% 5 \mathrm{bUNIQ} I D \% 5 \mathrm{~d}$ 